\title{
The use of ICT among Teachers of Science and Non- science Subjects in Private and Public Secondary Schools in Tanzania: A case of Dodoma Municipality
}

\author{
Gilbert M. Gilbert \\ College of Informatics and \\ Virtual Education, \\ University of Dodoma \\ Dodoma, Tanzania
}

\author{
Abbas Ismail \\ College of Mathematical and \\ Natural Sciences, \\ University of Dodoma \\ Dodoma, Tanzania
}

\author{
Majuto Manyilizu \\ College of Informatics and \\ Virtual Education, \\ University of Dodoma, \\ Dodoma, Tanzania.
}

\begin{abstract}
In Tanzania, there have been conceited efforts to integrate various technologies, particularly, Information and Communication Technology (ICT) in the education system. The key stakeholders for these efforts are teachers who are working at the very base of the Tanzanian education systems which include primary schools and secondary schools. The private sector has embarked the same initiatives to utilize ICT in teaching and learning processes. In this paper, a comparison in the extent of the utilization of ICT among teachers of science and non-science subjects in both private and public schools in Tanzania is studied, a case of Dodoma municipality. The study employed Chi-Square distribution technique and it reveals that there is no relationship between teachers of science and non-science in the use of ICT tools and ICT applications. However, there is a significant relationship in the use of ICT and attending ICT short training and vice versa. Such knowledge contributes to the understanding of the ICT training schemes to secondary school teachers and the possibility of providing specialized ICT training according to whether teachers are involved in science or non-science subjects.
\end{abstract}

\section{General Terms}

ICT, use of ICT, secondary schools, science and non-science

\section{Keywords}

ICT, use of ICT, ICT tools, ICT applications, secondary schools, private and public

\section{INTRODUCTION}

In the $21^{\text {st }}$ century, education and technology have become important driving-force behind social, economical and political developments in both developed and developing worlds. Several countries have been encouraging and investing in the fusion of these fundamental elements in their development strategies to gain competitive advantages in increasingly global economic competition. As education influences technology so as technology influences education, and it is the pace of technological change that many countries in the world are trying to come into terms with by updating their workforce skills in terms of offering appropriate education that tap the potentials of technology. Thus, effective use of Information and Communication Technology (ICT) in education has become fundamental milestone in the developed and developing worlds to enhance quality of teaching and learning processes.

However, in realizing the efforts of ICT utilization, particularly in secondary schools, it is vital that teachers are prepared well enough to integrate ICT in their teaching- learning processes. ICT utilization by secondary school teachers is equally as important as determining the usage levels in their subjects and impact on students. Research shows that ICT is accepted by significant number of teachers in secondary schools as a pedagogical tool to enhance learning processes (e.g. Cox et al., 2003). Access to ICT resources, knowledge of ICT in education and confidence in using ICT are important factors in influencing the use of ICT by secondary school teachers (Cox et al., 2003). Most of these factors that enable teachers to use ICT are related to their own beliefs and skills such as attitude, teaching priority, computer skills and teaching preferences (Bakar, 2007). Institutional factors can also contribute to the way teachers will consume ICT in their teaching processes. Some researchers reported that teachers are more likely to have positive perception on the ease of use of ICT if they have their own laptops and access to schools' computers (e.g. Cox et al, 1999) to integrate ICT in their teaching (e.g. Scrimshaw, 2004). Teachers are also on the opinion that if they receive adequate training on the use of ICT in teaching and are involved in formulating policies on using ICT across curriculum, they would be encouraged in technology use.

In Tanzania, there have been conceited efforts to integrate these technologies, in particular ICT in the education system. Such integration of ICT in education may be seen as a tool to promote autonomous learning, curriculum differentiation (Smeets 2005), student-centered learning, high order thinking, problem-solving (Smeets and Mooij 2001; Bangert 2008), clarification of abstract concepts and transformation of the understanding of the subject matter (Leach and Moon 2000). These efforts to harness the potential of ICT have been documented in various research articles (e.g. Senzige and Sarukesi 2003; Unwin 2005; Tilya 2007; Swarts and Wachira 2010).

The Ministry of Education in Tanzania have devised a number of inclusions of aspects of ICT in the curriculum that is used in various institutions to train prospective teachers (Mwalongo 2011). It is, therefore, expected that most of the teachers to have at least basic knowledge and skills to use ICT applications and tools in preparing their lessons, conducting research and communicating with other parties. Although some research studies in Tanzania indicate that teachers use ICT (MoCT 2003; Foundation 2007; Tilya 2007; Swarts and Wachira 2010) but other studies show that secondary school teachers still lack competencies in using ICT in their teachinglearning processes (Nihuka and Voogt, 2011; Bingmlas, 2009). Moreover, there is no much clear information of the extent of use of ICT among teachers of different subjects, 
particularly science and non-science subjects in secondary schools in Tanzania. This is the subject for this paper.

The aim of this study is to assess the use of ICT among teachers in science and non-science areas in both private and public secondary schools in Dodoma municipality. Dodoma region is the capital city of Tanzania, located at the center of the country, and has seven districts with a total of 215 secondary schools (Report to President 2014). Dodoma municipality which is the headquarters of the region has 37 secondary schools with 1,118 teachers as of 2014 (Report to President, 2014). Compared to other regions in Tanzania, Dodoma secondary schools have been performing poorly in national examinations. The research paper presents the current situation of the use of ICT between teachers and recommends strategies and solutions to be used by policy makers to improve the use of ICT among teachers of secondary schools.

This paper is organized as follows: The introductory part (Section 1) is followed by Section 2 which describes the proposed methodology used in the study. Section 3 presents findings and discussion of the results. Section 4 includes conclusion remarks and future work.

\section{Research questions/ Study Objective}

The main objective of this study is to find out the distribution of ICT use among secondary school teachers with respect to their subjects which they teach, particularly science and nonscience in Tanzania with a case study of Dodoma Municipality. The objective of the study is achieved by addressing the following questions:

- To what extent do secondary school teachers of science and non-science subjects use ICT applications and tools in teaching?

- To what extent do teachers of science and nonscience subject use ICT in relation to ICT short training attendance?

- Between private and public secondary schools whom teachers (of science and non-science subjects) make the most use of ICT?

\section{METHODOLOGY}

This study involved a case study/ cross- section method in which the aim was to get an in-depth understanding of teachers' ICT use.

\subsection{Research design}

\section{Sampling}

The sample was taken from teachers in some selected secondary schools in Dodoma municipality where both private and public schools were included. A total of 231teachers took part in the research. The table (Table 1) below summarizes the characteristics of teachers. Table 2 shows the distribution of teachers in private and public secondary schools in relation to their sex and subject which they teach.

Table 1: Characteristics of the respondents

\begin{tabular}{|l|l|l|l|}
\hline Covariate & Response & Frequency & Percentage \\
\hline \multirow{2}{*}{ Sex } & Male & 120 & 51.9 \\
\cline { 2 - 4 } & Female & 111 & 48.1 \\
\hline Age & $18-25$ & 16 & 6.9 \\
\hline
\end{tabular}

\begin{tabular}{|l|l|l|l|}
\hline \multirow{4}{*}{} & $26-35$ & 149 & 64.5 \\
\cline { 2 - 4 } & $36-45$ & 43 & 18.6 \\
\cline { 2 - 4 } & Above 45 & 23 & 10.0 \\
\hline $\begin{array}{l}\text { Maximum } \\
\text { level of } \\
\text { education } \\
\text { reached }\end{array}$ & Form VI & 1 & 0.4 \\
\cline { 2 - 4 } & Certificate & 2 & 0.9 \\
\cline { 2 - 4 } & Diploma & 53 & 22.9 \\
\cline { 2 - 4 } & First degree & 175 & 75.8 \\
\hline $\begin{array}{l}\text { Number of } \\
\text { years in the } \\
\text { teaching } \\
\text { carrier }\end{array}$ & $\begin{array}{l}\text { Less than } 5 \\
\text { years }\end{array}$ & 101 & 43.7 \\
\cline { 2 - 4 } & $5-10$ years & 86 & 37.2 \\
\cline { 2 - 4 } & $11-20$ years & 24 & 10.4 \\
\cline { 2 - 4 } & $21-30$ years & 12 & 5.2 \\
\cline { 2 - 4 } & $\begin{array}{l}\text { More than } 30 \\
\text { years }\end{array}$ & 8 & 3.5 \\
\hline & Public schools & 9 & 54 \\
\cline { 2 - 4 } $\begin{array}{l}\text { Distribution } \\
\text { of the type } \\
\text { of school }\end{array}$ & Private schools & 7 & \\
\hline
\end{tabular}

Table 2: Gender Distribution

\begin{tabular}{|c|c|c|c|}
\hline \multirow[t]{2}{*}{ Gender } & \multirow{2}{*}{$\begin{array}{l}\text { Type of } \\
\text { school }\end{array}$} & \multicolumn{2}{|c|}{ Subject Type } \\
\hline & & Science & Non Science \\
\hline \multirow[t]{2}{*}{ Male } & Public & 20 & 35 \\
\hline & Private & 19 & 45 \\
\hline \multirow[t]{2}{*}{ Female } & Public & 11 & 77 \\
\hline & Private & 4 & 19 \\
\hline
\end{tabular}

\subsection{Data Collection}

Data was collected using a single source. It involves questionnaire, closed-ended oriented, because this is a quantitative study. Furthermore, this technique is conveniently used because it was cheaper and easy to administer and manage (Cooper and Emory, 2008) the collection of data from teachers in selected secondary schools.

The questionnaire that was used in the study consisted of questions that focused on gender and age, education levels (ordinary level, advanced level, certificate, diploma, degree, other), years of teaching experience (less than 5, 5-10, 11-20, 21-30, more than 30), subject taught (science, art, business, other), ICT tools used in teaching (projector and computer, internet use), and ICT applications (spreadsheets, word processors, internet and email ) used in preparing and presenting learning materials. Information about whether the participants teach in public or private schools was also captured. A total of 229 questionnaires were received.

\subsection{Methods of data analysis}

The data that were gathered for this study were edited and cleaned to improve consistency, and then summarized and coded to assist in interpreting descriptive statistics as well as depicting the response pattern. Apart from science subjects, Art, Business and other subjects were treated as non-science subjects throughout the analysis, interpretation and discussion. Also, in the context of this research, ICT tools involve electronic teaching aids such as projectors and computers. ICT applications involve spreadsheets, word processors, internet and email. Statistical Package for Social Sciences 
(SPSS) version 22 was used as a computer software to facilitate the process of generating statistics.

\section{RESULTS AND DISCUSSION}

\subsection{The Use Of ICT Tools Among Science And Non-Science Subject Teachers In Delivering Content}

Respondents were asked to indicate which ICT tools they use for teaching and preparing learning materials. As shown in Figure 1, more than a half of the respondents were reported that they do not make use of any ICT tool in delivering their content in which $53.7 \%$ are from science subjects and 55.4\% from non-science subjects. Science subject teachers were observed to make relatively high efforts on the use of computers and projectors (13\%) compared to non-science subject teachers $(5.7 \%)$. These results suggest that, although teachers have positive attitudes toward the use of ICT (Teo 2008, Ndibalema 2014), efforts should be made to ensure availability of ICT facilities and an environment in which ICT can be used frequently and effectively (Cubukcuoglu 2013).

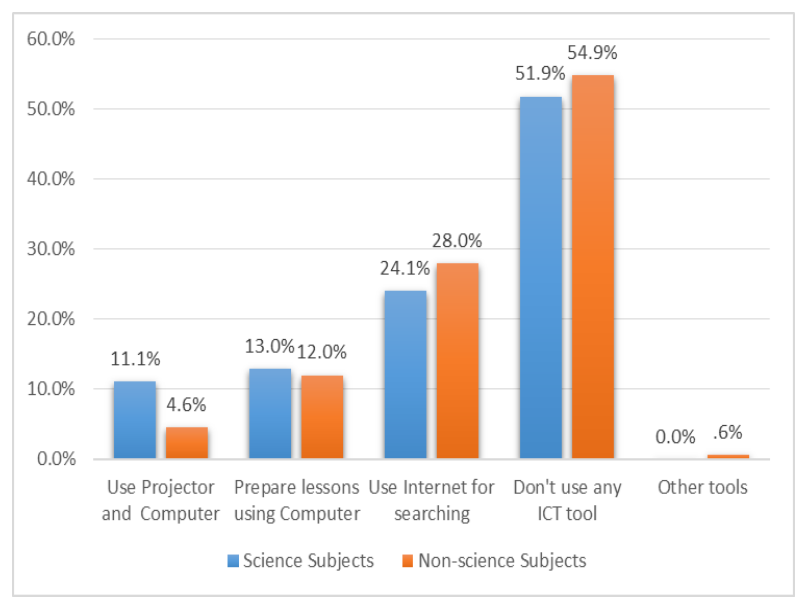

Figure 1. The use of ICT tools in delivering content

\subsection{ICT Short Training Attendance Among Science And Non-Science Subject \\ Teachers}

Teachers were asked to respond to the type of ICT short training that they have attended on ICT basic course, Web design/multimedia and a course related to ICT teaching and learning integration. In Figure 2, it can be seen that, both science and non-science subject teachers constituted $53.7 \%$ and $59.3 \%$, accordingly of those who have basic skills in ICT by attending ICT training. This result comes to an agreement with the finding of Lau and Sim (2008) which indicates that most of the teachers considers themselves as having limited knowledge of ICTs and had to find ways to improve their skills. About $4.5 \%$ of the respondents admitted taking courses in web design and multimedia which also suggest that these ICT applications are too specialized and they rarely use them. About $24.9 \%$ reported that, they did not attend any ICT course.

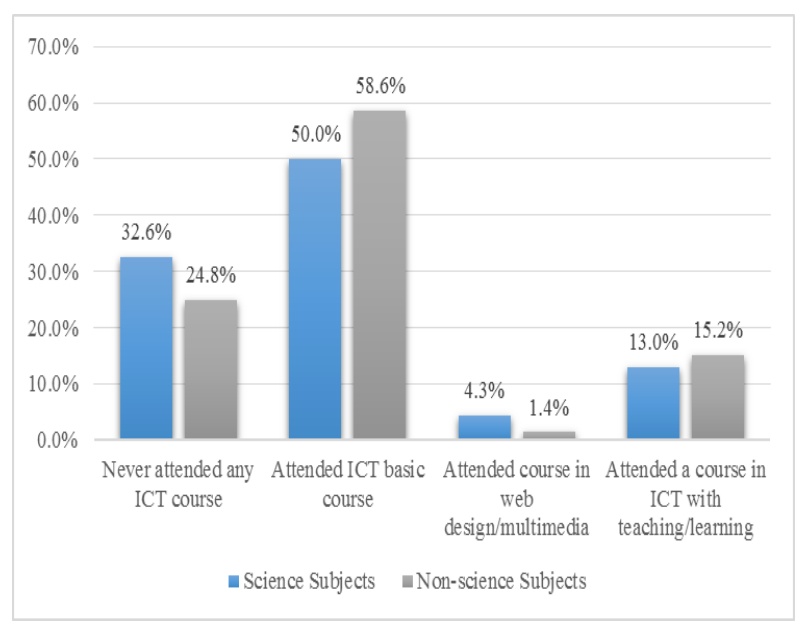

Figure 2: ICT short course attendance among science and non-science subject teachers

Table 3 captures the analysis done statistically to determine the differences in the extent of use of ICT tools and attendance in ICT short training among science and nonscience subject teachers. As it can be seen from the p-values column, p-values of about 0.7 and 0.3 were obtained respectively to suggest that there are no significances ( $p$ values $>0.05$ ), which means that there were comparable use of ICT and ICT short training attendances between science and non-science teachers.

\subsection{The use of ICT applications in teaching and learning processes among science and non-science subject teachers in relation to the type of school}

For teachers' ICT competence, the respondents were asked to choose ICT applications which include Spreadsheets, Word Processors, Databases, Desktop Publishing, Internet and Email that they use in teaching and learning processes. As shown in Figure 3, almost half $(48.1 \%)$ of teachers make use of word processors which is in agreement by observations made by Cuckle et al. (2000). Science subject teachers were reported to make more use of Database, Desktop publishing, Internet and Email applications than their counterpart nonscience subject teachers. As also observed by Mwalongo (2011), E-mail is almost equally used by responds and is mostly used for personal communication, and Internet for searching materials.

\subsection{The Use Of ICT Among Science And Non-Science Subject Teachers In Relation To Whether The School Type}

Table 4 and Table 5 compare the use of ICT tools and ICT short course attendance in relation to the type of schools, that is, private or public. From the results, it could be argued that ICT tools and ICT short course attendance have no relation to whether a teacher is from public or private school. Moreover, there is no relation to whether a teacher teaches science or non-science subjects. A notable difference could be reported on those who responded no to the use of ICT tools in which a p-value of 0.024 was recorded. 


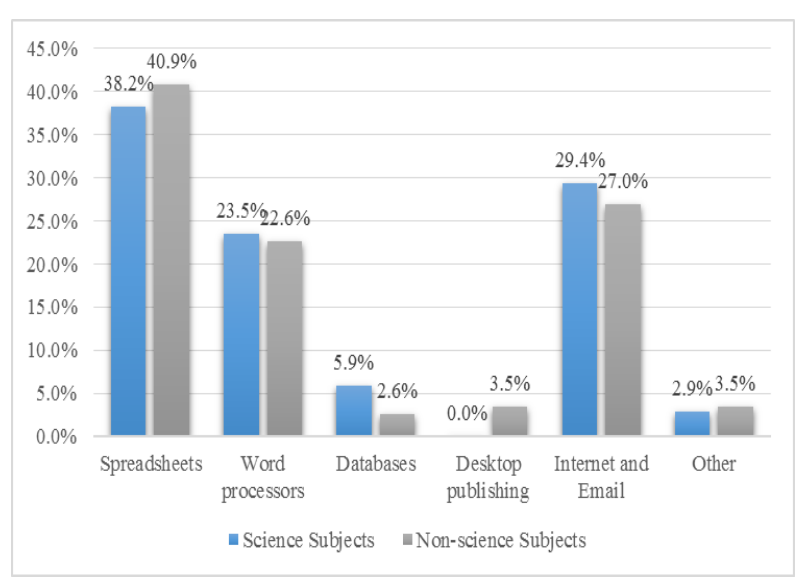

Figure 3: ICT applications use among science and nonscience subject teachers

Table 5 reveals the summary of the analyses in which a Pearson Chi-Square values were obtained to establish the relationship and significance in the use of ICT application between science and non-science subject teachers with respect to the type of the schools they teach. Generally, there were no significances in the use of ICT applications.

Table 3: ICT use and ICT training attendance among science and non-science teachers

\begin{tabular}{|l|l|l|l|l|}
\hline $\begin{array}{c}\text { Covariat } \\
\text { e }\end{array}$ & Response & $\begin{array}{l}\text { Science (n, ( } \\
\text { \%)) }\end{array}$ & $\begin{array}{l}\text { Non- } \\
\text { Science } \\
(\mathbf{n ,}(\boldsymbol{\%}))\end{array}$ & $\begin{array}{l}\boldsymbol{P} \text { - } \\
\text { values }\end{array}$ \\
\hline \multirow{2}{*}{ ICT Tools } & Yes & $26(25.0)$ & $78(75.0)$ & $\mathbf{. 6 6 9}$ \\
\cline { 2 - 4 } & No & $28(22.6)$ & $96(77.4)$ & \\
\hline $\begin{array}{l}\text { ICT } \\
\text { training }\end{array}$ & Yes & $31(22.1)$ & $\begin{array}{l}109 \\
(77.9)\end{array}$ & \multirow{2}{*299}{} \\
\cline { 2 - 4 } & No & $15(29.4)$ & $36(70.6)$ & \\
\hline
\end{tabular}

Table 4: The use of ICT tools and ICT training among science and non-science teachers in private $(\mathbf{P})$ and government (G) (public) secondary schools

\begin{tabular}{|c|c|c|c|c|c|}
\hline $\begin{array}{l}\text { Covariat } \\
\text { e }\end{array}$ & Response & $\begin{array}{l}\text { Type } \\
\text { of } \\
\text { school }\end{array}$ & $\begin{array}{l}\text { Science } \\
(\mathbf{n},(\%))\end{array}$ & $\begin{array}{l}\text { Non- } \\
\text { science } \\
(\mathbf{n},(\%))\end{array}$ & $\begin{array}{l}\text { p- } \\
\text { values }\end{array}$ \\
\hline \multirow[t]{4}{*}{ ICT tools } & \multirow[t]{2}{*}{ Yes } & $\mathrm{G}$ & $11(21.2)$ & $41(78.8)$ & \multirow[t]{2}{*}{.821} \\
\hline & & $\mathrm{P}$ & $15(28.8)$ & $37(71.2)$ & \\
\hline & \multirow[t]{2}{*}{ No } & G & $15(65.2)$ & $37(58.7)$ & \multirow[t]{2}{*}{.024} \\
\hline & & $P$ & $8(23.5)$ & $26(76.5)$ & \\
\hline \multirow{4}{*}{$\begin{array}{l}\text { ICT } \\
\text { training }\end{array}$} & Yes & G & $20(22.2)$ & $70(77.8)$ & \multirow[t]{2}{*}{1.739} \\
\hline & & $\mathrm{P}$ & $5(45.5)$ & $6(55.5)$ & \\
\hline & No & $\mathrm{G}$ & $17(21)$ & 64(79) & \multirow[t]{2}{*}{.149} \\
\hline & & $\mathrm{P}$ & $14(23.7)$ & $45(76.3)$ & \\
\hline
\end{tabular}

Table 5: The use of ICT applications among science and non-science teachers in private and government (public) secondary schools

\begin{tabular}{|l|l|l|l|l|l|}
\hline \multicolumn{2}{|c|}{ Covariate } & $\begin{array}{l}\text { Type of } \\
\text { School }\end{array}$ & $\begin{array}{l}\text { Science } \\
(\mathbf{n},(\%))\end{array}$ & $\begin{array}{l}\text { Non- } \\
\text { Science } \\
(\text { n,( \%)) }\end{array}$ & $\begin{array}{l}\text { P- } \\
\text { value }\end{array}$ \\
\hline $\begin{array}{l}\text { ICT } \\
\text { applicat }\end{array}$ & $\begin{array}{l}\text { Spread } \\
\text { sheets }\end{array}$ & P & $7(24.1)$ & $22(75.9)$ &. $\mathbf{. 2 0 2}$ \\
\cline { 3 - 6 } & G & $6(19.4)$ & $25(80.6)$ & \\
\hline
\end{tabular}

\begin{tabular}{|l|l|l|l|l|l|}
\hline ions & \multirow{2}{*}{$\begin{array}{l}\text { Word } \\
\text { Processors }\end{array}$} & $\mathrm{P}$ & $7(53.8)$ & $6(46.2)$ & $\mathbf{1 0 . 7 5 1}$ \\
\cline { 3 - 6 } & $\mathrm{G}$ & $1(4.8)$ & $20(95.2)$ & \\
\cline { 2 - 6 } & Databases & $\mathrm{P}$ & $0(0)$ & $2(100)$ & $\mathbf{2 . 2 . 2 2}$ \\
\cline { 3 - 6 } & $\mathrm{G}$ & $2(66.7)$ & $1(33.3)$ & \\
\cline { 2 - 6 } & $\begin{array}{l}\text { Desktop } \\
\text { Publishing }\end{array}$ & $\mathrm{P}$ & $0(0)$ & $1(100)$ & $\mathbf{a}$ \\
\cline { 2 - 5 } & $\mathrm{G}$ & $0(0)$ & $3(100)$ & \\
\cline { 2 - 6 } & $\begin{array}{l}\text { Internet } \\
\text { and Email }\end{array}$ & $\mathrm{P}$ & $6(30)$ & $14(70)$ & $\mathbf{. 6 6 6}$ \\
\cline { 2 - 6 } & $\mathrm{G}$ & $4(24.4)$ & $17(75.6)$ & \\
\cline { 2 - 6 } & \multirow{4}{*}{ Others } & $\mathrm{P}$ & $0(0)$ & $0(0)$ & $\mathbf{b}$ \\
\cline { 3 - 6 } & & $\mathrm{G}$ & $1(20)$ & $4(80)$ & \\
\hline
\end{tabular}

$\mathrm{a}$ and b can't be computer because some variables are constant

\section{CONCLUSION AND FUTURE WORK}

The results of this research showed that there are similar extent of use of ICT tools and applications among secondary school teachers of science and non-science subjects in Tanzania. This could be attributed to the fact that both groups are exposed to similar settings of ICT training during their college education. The ministry responsible for teachers' training should ensure that provisional of ICT training to teachers is treated according to the profession of these teachers who are taking for proper use of ICT in secondary education.

Future work will now link the possibility of providing specialized ICT training to teachers of science and nonscience.

\section{ACKNOWLEDGEMENT}

This research is supported by Carnegie-SIG Regional Initiative in Science and Education (RISE) through its competitive fund award for supporting this research. Special thanks to Computation and Modelling Research Group at University of Dodoma for the support on technical and academic issues regarding this publication. Moreover, this study wouldn't have been possible without a generous support from the management of secondary schools in Dodoma municipality.

\section{REFERENCES}

[1] Teo, T. (2008). Pre-service teachers' attitude towards computer use: A Singapore survey. Australian Journal of Educational Technology, 23(4)

[2] Cubukcuoglu, B. (2013). Factors enabling the use of technology in subject teaching. International Journal of Education and Development using Information and Communication Technology (IJEDICT), Vol. 9, Issue 3, pp. 50-60424.

[3] Ndibalema, P (2014). Teachers' Attitudes towards the Use of Information Communication Technology (ICT) as a Pedagogical Tool in Secondary Schools in Tanzania: The Case of Kondoa District International Journal of Education and Research 2(2).

[4] Lau, B. and Sim, C (2008). Exploring the extent of ICT adoption among Secondary School Teachers in Malaysia. International Journal of Computing and ICT Research,II(II),19-36.

[5] Cuckle, P., CLarke, S., and Jenkins, I. 2000. Students' information and communications technology skills and their use during teacher training. Journal of InformationTechnology for Teacher Education, 9(1), 922. 
[6] JEGEDE, P.O., ODUSOLA O.D., ILORI, M.O. 2007. Relationships between ICT competence and attitude among Nigerian Tertiary Institution Lecturers. Educational Research and Review Vol. 2(7), pp. 172 175, July, 2007.

[7] Report to President. 2014. Taarifa ya mkoa wa Dodoma iliyotolewa kwa rais wa Jamhuri ya Muungano wa Tanzania mhe. Dkt. Jakaya Mrisho Kikwete agosti 2014

[8] GRAY, D.S., SOUTER, N. 2004. Secondary science teachers' use of and attitude towards ICT in Scotland. A Report, University of Strathclyde, Glasgow, UK.

[9] Smeets, E., \& Mooij, T. (2001). Pupil-centered learning, ICT, and teacher behaviour: observations in educational practice. British Journal of Educational Technology, 32(4), 403-418.

[10] Bangert, A. W. (2008). The development and validation of the student evaluation online teaching effectiveness. Computers in the Schools, 25(1), 25-47.

[11] LEACH, J. \& MOON, B. (2000). 'Pedagogy, information and communications technology and teachers' professional knowledge', The Curriculum Journal, 11, 3, 385-404.

[12] Tilya, F. 2007, ICT in education in Tanzania: Lessons and experiences from IICD-supported projects, International Institute for Communication Development, The Hague.

[13] Unwin, T. 2005, 'Towards a framework for the use of ICT in teacher training in Africa', Open Learning, vol. 20, no. 2, pp. 113 - 129.

[14] Swarts, P. and Wachira, E. M. 2010, Tanzania: ICT in education situational analysis, Global e-School and Communities Initiative
[15] Mwalongo, A. 2011. Teachers' perceptions about ICT for teaching, professional development, administration and personal use. International Journal of Education and Development using Information and Communication Technology (IJEDICT), 2011, Vol. 7, Issue 3, pp. 36-49.

[16] Nihuka, K.A. and Voogt, J. (2011). Instructors and Students Competences, Perceptions and Access to Elearning Technologies: Implications for E-learning Implementation at the Open University of Tanzania. International Journal on E-Learning, 10(1), 63-85.

[17] Bingimlas, K. A. (2009). Barriers to the Successful Integration of ICT in Teaching and Learning Environments: A Review of the Literature. Eurasia Journal of Mathematics, Science and Technology Education, Vol. 5 (3), 235-245.

[18] Cox, M., Preston, C. and Cox, K. (1999) What Factors Support or Prevent Teachers from Using ICT in their Classrooms? In British Educational Research Association Annual Conference.

[19] Cox, M., Webb, M., Abbott, C., Blakely, B., Beauchamp, T. and Rhodes, V. (2003) ICT and pedagogy: A review of the research literature (London: DfES and Becta).

[20] Bakar, N. A. 2007. "Factors that contribute to the effective use of computers in the classroom: The Malaysian context". AsiaCall Online Journal, vol.2, Issue 1, pp. 26-33.

[21] Scrimshaw, P. 2004. Enabling teachers to make successful use of ICT. Coventry: BECTA.

[22] Cooper, D. R., \& Emory, C. W. (2008). Business Research Methods (5th edition). USA: Richard D. Irwin. 